\title{
A New Strain of Bacteria Degrading TNT and 2,4/2,6-DNT From Explosives - Contaminated Soil
}

\author{
Jinsoo Kim ${ }^{1}$, Yong-Kju Yu², Fei Yan ${ }^{3}$, John Bang ${ }^{4}$, Taek You ${ }^{5}$, and Sang-Seob Lee ${ }^{1 *}$
}

${ }^{1}$ Department of Life Science, Kyonggi University, Suwon, Korea 442-760; ${ }^{2}$ Department of Biological Engineering, Kyonggi University, Suwon, Korea 442-760; ${ }^{3}$ Department of Chemistry, North Carolina Central University, NC, USA; ${ }^{4}$ Department of Environmental, Earth, and Geospatial Sciences, North Carolina Central University, Durham, NC 27707, USA; ${ }^{5}$ Department of Biological sciences, Campbell University, Buies Creek, NC 27506, USA

Received: May 17, 2012 / Accepted: June 17, 2012

\begin{abstract}
The 2,4,6-trinitrołolvene (TNT), 2,4-dinitrołolvene (2,4-DNT), and Tolvene derived from a nitroaromatic compound(NAC) cause high toxicity and mutagenicity to environment. One of best methods to remove their toxicity from contaminated soil is known biological remediation with soil bacteria. Total of $\mathbf{2 3 5}$ strains of explosives-removing soil bacteria were isolated from the shooting gallery at a military base in Korea. They were identified as Acinetobacter, Agrobacterium, Alcaligenes, Flavobacterium, Klebsiella, Pseudomonas, Serratia, and Citrobacter species. After further screened for the better removal efficiencies, KT22 identified as Serratia sp., KD4 identified as Klebsiella sp., and KD6 identified also as Klebsiella sp. showed the highest removal efficiency for TNT, 2,4DNT, and 2,6-DNT, respectively. The optimal removal conditions were shown as follows: cell concentration $1 \mathrm{~g} / \mathrm{L}, \mathrm{pH}$ 7 , and temperature $25-30^{\circ} \mathrm{C}$. In a Luria-Bertani (LB) medium containing $100 \mathrm{mg} / \mathrm{L}$ of TNT, KT22 strain could remove TNT over $99 \%$ and showed a good biomass growth after $6 \mathrm{~h}$ of incubation. Furthermore, when the KT22 strain was mixed with a Bacillus sp., the mixed culture showed the improved TNT removal efficiency. Conclusively, this new strain could be most effective to remove NAC toxicity with rhizosphere remediation system on contaminated soil.
\end{abstract}

* Corresponding author: sslee@kyonggi.ac.kr

\section{Introduction}

2,4,6-trinitrotoluene (TNT) is a nitroaromatic compound (NAC) commonly used in explosives, and 2,4-dinitrotoluene (2,4-DNT) and 2,6-dinitrotoluene (2,6-DNT) are two of the six DNT isomers that are used primarily as chemical intermediates in the production of toluene diamines and diisocyanates, dyes, explosives, and propellants. Two products derived from TNT are 2,4-dinitrotoluene (DNT) and toluene (Spanggord et al., 1991; Duque et al., 1993). These toxic compounds are often the main contaminants of soil and groundwater at their manufacturing, processing, and disposal facilities (Kalafut et al., 1998). Especially, TNT has been widely used during and even after WWII, resulting in widespread soil contamination (Scheibner et al., 1997), and was also used throughout the entire Korean peninsula during the Korean War.

The high toxicity and mutagenicity of TNT and some of its metabolites have led to a harmful effect in their fates in the environment. Numerous cases of munitions workers who have developed liver damage and anemia owing to the TNT exposure have been documented (Voegtlin et al., 1919; Hamilton, 1921; Bridge et al., 1942; Sax, 1963). In addition, TNT has been shown to have toxic effects in rats and mice (Dale, 1921; Channon et al., 1994), fish, algae, and oyster larvae (Smock et al., 1976; Won et al., 1976). The International Agency for Research on Cancer (IARC) has also determined that 2,4- and 2,6-DNT are possibly carcinogenic to humans. In addition, 2,6-DNT showed hepatocarcinogenic effects in Fischer-344 rats, and exposure to 
high levels of DNTs in animals caused lowered numbers of sperm and reduced fertility (Popp, 1983; Richart, 1984).

The most practical approach toward the remediation of explosives is currently soil incineration, but it can be a costly, energy-intensive process that destroys much of the soil, leaving ash as the primary residue with estimates approaching $\$ 800 /$ ton (Funk et al., 1993). Chemical treatment, on the other hand, requires the exercise of rigid controls to avoid the discharge of unreacted materials and is not practical in many situations. It is believed that biological remediation of explosives is the most economical and reliable method of response to this problem at a cost that ranges \$30-\$150/yd3 (Montemagno and Irvine, 1990; Preslan et al., 1993). Composting, one of the biological remediation methods applied to explosives, has been proven to be effective and is compatible with the incineration method (Williams et al., 1992). Bio-treatment with bacteria has focused on less expensive method of bioremediation, because many different species of bacteria potentially reduce nitro groups on the aromatic ring in soil with no requirement for additional nutrients.

Recently researchers have tried to hybrid more than two techniques to overcome weak points of each technique, and improve efficiency in the remediation fields. For instance, phytoremediation, which is a combined technique with bioremediation using soil bacteria and plant, was applied to remediate the contaminated soil. For NAC group is fairly toxic and combined one is applied to various environmental conditions, bacteria which could degrade TNT under aerobic and/or anaerobic condition are required to grow well with other organisms.

To develop an enhanced rhizosphere remediation system with NAC removing soil bacteria, we were isolated and identified them in this study. Then, they were further screened for high removal efficiencies toward TNT and 2,4/2,6-DNT, using batch tests. Effects of pure vs. mixed culture with common soil microbes on the removal efficiencies were also evaluated.

\section{Materials and Methods}

\section{Isolation, Cultivation, and Identification of Explosives-Removing Soil Bacteria}

All the samples for the microbial isolation were obtained from the shooting gallery at a military base in Kyonggi-province, Korea. Samples were obtained with the bottom soil, and the $\mathrm{pH}$ and temperature were $5.6,9.5-10.5^{\circ} \mathrm{C}$, respectively.

Four different types of media, i.e., nutrient broth, Medium 1, Medium 2, and King's B medium, were used as the growth medium for culturing TNT and 2,4/2,6-DNT removing bacteria. The composition of each medium was as follows per liter of deionized water. Nutrient broth: Bacto beef extract $3.0 \mathrm{~g}$, Bacto peptone 5.0g, TNT $0.1 \mathrm{~g}$; Medium 1: $\mathrm{K}_{2} \mathrm{HPO}_{4} 7.0 \mathrm{~g}, \mathrm{KH}_{2} \mathrm{PO}_{4}$ $3.0 \mathrm{~g}, \mathrm{MgSO}_{4} 0.1 \mathrm{~g}, \mathrm{NaCl} 0.1 \mathrm{~g}, \mathrm{NH}_{4} \mathrm{Cl} 0.25 \mathrm{~g}$, peptone $0.5 \mathrm{~g}$, yeast extract $0.1 \mathrm{~g}$, succinate $5.0 \mathrm{~g}$, and TNT $0.1 \mathrm{~g}$; Medium 2: $\mathrm{MgSO}_{4} 0.1 \mathrm{~g}, \mathrm{~K}_{2} \mathrm{HPO}_{4} 3.5 \mathrm{~g}_{2} \mathrm{KH}_{2} \mathrm{PO}_{4} 1.5 \mathrm{~g}$, TNT $0.1 \mathrm{~g}$, yeast extract $1.0 \mathrm{~g}$, and trace element solution $1.0 \mathrm{~mL}$, consisting of ethylenediaminetetraacetic acid (EDTA) $0.25 \mathrm{~g}$, $\mathrm{FeSO}_{4} \cdot 7 \mathrm{H}_{2} \mathrm{O}$ $0.1 \mathrm{~g}$, and trace element solution SL-6 $1.0 \mathrm{~mL}$; King's B medium: peptone $20.0 \mathrm{~g}_{2} \mathrm{~K}_{2} \mathrm{HPO}_{4} 1.5 \mathrm{~g}$, and $\mathrm{MgSO}_{4} \cdot 7 \mathrm{H}_{2} \mathrm{O} 1.5 \mathrm{~g}$. Agar at $1.5 \%(\mathrm{w} / \mathrm{v})$ was added for the solid medium. The explosive stock solution was prepared by dissolving $0.5 \mathrm{~g}$ TNT in $50 \mathrm{~mL}$ $\mathrm{N}, \mathrm{N}$-dimethylformamide to have a final concentration of 10,000 $\mathrm{mg} / \mathrm{L}$. The final TNT concentration of test media was adjusted to $100 \mathrm{mg} / \mathrm{L}$ using stock solution.

In case of aerobic cultivation, $20 \mathrm{~mL}$ cultivation solution was added in a $100 \mathrm{~mL}$ flask, inoculated, and then cultivated. Facultative anaerobic cultivation was performed using test tubes full of the medium. Cultures were incubated at $28 \pm 2^{\circ} \mathrm{C}$.

For the identification of isolates, Gram staining and biochemical tests were performed. Cell size, motility, and morphology were determined microscopically $(x 1,000)$ under the light microscope (Olympus BH-2, Japan). Chracteristics of the results were compared with the properties described in the Bergey's Manual of Systematic Bacteriology (Krieg et al., 1994). For genetic characteristics, the $16 \mathrm{~S}$ rRNA gene was amplified by PCR with $27 F / 1492 R$ primers (universal primers for bacteria) in 35 amplification cycles at $94^{\circ} \mathrm{C}$ for $45 \mathrm{sec}, 55^{\circ} \mathrm{C}$ for $60 \mathrm{sec}$, and $72^{\circ} \mathrm{C}$ for $60 \mathrm{sec}$. For purification of PCR products, unincorporated PCR primers and $\mathrm{dNTPs}$ from PCR products were removed by using the Montage PCR Clean up kit (Millipore Co., USA). The purified PCR products were sequenced by using 27F/ 1492R primers. Sequencing was performed by using Big Dye terminator cycle sequencing kit v.3.1 (Applied BioSystems, USA). Sequencing products were resolved on an Applied Biosystems model 3730XL automated DNA sequencing system (Applied BioSystems, USA) at the Macrogen, Inc., Seoul, Korea. The nearly complete sequence of the $16 \mathrm{~S}$ rRNA gene (1427nt) was compiled with SeqMan software (DNASTAR Inc.). The 165 rRNA gene sequences of the related taxa were obtained from GenBank.

\section{Screening of Highly Efficient Explosives-Removing Strains}

Each of those 235 isolated strains of soil bacteria was screened for the TNT and 2,4/2,6-DNT removal efficiencies, using a Luria-Bertani (LB) medium containing $100 \mathrm{mg} / \mathrm{L}$ of TNT or 2,4/2,6-DNT, under aerobic conditions. After 12 and $18 \mathrm{~h}$ of cultivation, concentrations of TNT and 2,4/2,6-DNT were measured on a gas chromatograph (HP-6890, USA) equipped with the electron capture detector (GC-ECD) and RTX-TNT column. ECD has been widely used for the determination of NACs (Walsh, 2001 ). Nitrogen was used as a carrier gas at the flow rate of $60 \mathrm{~mL} / \mathrm{min}$. Injector and detector temperatures were 250 and $300^{\circ} \mathrm{C}$, respectively. The column temperature was programed as follows: held for $1 \mathrm{~min}$ at $80^{\circ} \mathrm{C}$; temperature increased to $180^{\circ} \mathrm{C}$ at the ratio of $10^{\circ} \mathrm{C} / \mathrm{min}$; temperature increased to $300^{\circ} \mathrm{C}$ at the ratio of $30^{\circ} \mathrm{C} / \mathrm{min}$; and held for $3 \mathrm{~min}$ at $300^{\circ} \mathrm{C}$.

\section{Batch Experiments for High Explosives Removal Efficiencies}

In order to determine the optimum culture conditions for the explosives-removing bacteria, the batch culture was performed under various conditions. For the effect of explosive concentration on bacterial growth rate, the bacterial cell concentration was set at $1.0 \mathrm{~g} \mathrm{WCW}$ (Wet Cell Weight)/L. TNT and 2,4/2,6DNT concentrations in $L B$ medium and basal mineral medium 
were modified to 10,100 , and $200 \mathrm{mg} / \mathrm{L}$, respectively. For the optimum cell concentration, TNT and 2,4/2,6-DNT concentrations in LB medium and basal mineral medium were set at 100 $\mathrm{mg} / \mathrm{L}$ but the bacterial cell concentrations were modified to 0.5 , 1.0 , and $1.5 \mathrm{~g} \mathrm{WCW} / \mathrm{L}$. For the optimum $\mathrm{pH}$ and temperature, $\mathrm{pH}$ was modified to $6,7,8$, and 9 and temperature to 15,20 , 25 , and $30^{\circ} \mathrm{C}$. In addition, to evaluate the possibility of even higher removal efficiencies for TNT and 2,4/2,6-DNT, the mixed cultures consisting of isolates mixed with either Bacillus strains, purple non-sulfur bacterial strains, or Pseudomonas strains, were compared with single cultures in terms of the TNT removal efficiency.

\section{Results and Discussion}

\section{Bacterial Isolation and Identification}

In total, 235 strains of soil bacteria were isolated from the military shooting gallery and they were identified as follows, according to the classification keys of Bergey's Manual of Systematic Bacteriology (Krieg et al., 1994): Acinetobacter (51 strains), Agrobacterium (2), Alcaligenes (2), Azorhizobium (15), Citrobacter (14), Flavobacterium (27), Hafnia (9), Klebsiella (8), Klyvera (16), Pantoea (5), Proteus (18), Pseudomonas (36), Serratia (22), and Yersinia (10).

Among 235 isolates, 168 strains could remove TNT and were identified as Pseudomonas (24), Flavobacterium (13), Citrobacter (14), Proteus (12), Yersina (6), Hafnia (4), Klyvera (15), Pantoea
(4), Klebsiella (4), Serratia (21), Azorhizobium (9), and Acinetobacter (42). Fifty one strains removed 2,4-DNT and were identified as Pseudomonas (11), Flavobacterium (13), Proteus (4), Agrobacterium (2), Yersina (4), Hafnia (3), Klyvera (1), Pantoea (1), Klebsiella (4), Serratia (1), Azorhizobium (1), and Acinetobacter (6). Sixteen strains removed 2,6-DNT and were identified as Acinetobacter (3), Alcaligenes (2), Azorhizobium (5), Flavobacterium (1), Hafnia (2), Proteus (2), and Pseudomonas (1) (Table 1). The other 77 strains were not shown explosives-removal efficiency, but could survive. The strains were tolerant to explosives as bacteriostatics.

For the screening of strains with high explosives removal efficiencies, 147 isolates were tested for TNT and 2,4/2,6-DNT removal. Results showed that 113 strains removed TNT at the average removal efficiency of $84.4 \%, 27$ strains removed 2,4DNT at the average efficiency of $89.8 \%$, and 7 strains removed 2,6 -DNT at the average efficiency of $72.6 \%$. Among these isolated tested, KT22 strain showed the highest removal efficiency for TNT (100\%, after 6 h), KD4 strain for 2,4-DNT (100\%, after $18 \mathrm{~h})$, and KD6 strain for 2,6-DNT (97.7\%, after $18 \mathrm{~h}$ ), respectively (Table 2). High efficiency bacteria KT22 was identified as Serratia sp., and KD4 and KD6 were identified as Klebsiella sp. (Figure 1, Table 3). On the basis of the $16 \mathrm{~S}$ rRNA gene sequences revealed that strain KT22 showed the high sequence similarity to Serratia marcescens (100\%), strain KD4 and KD6 showed the high sequence similarity to Klebsiella oxytoca $(99 \%)$ as Blast searching results.
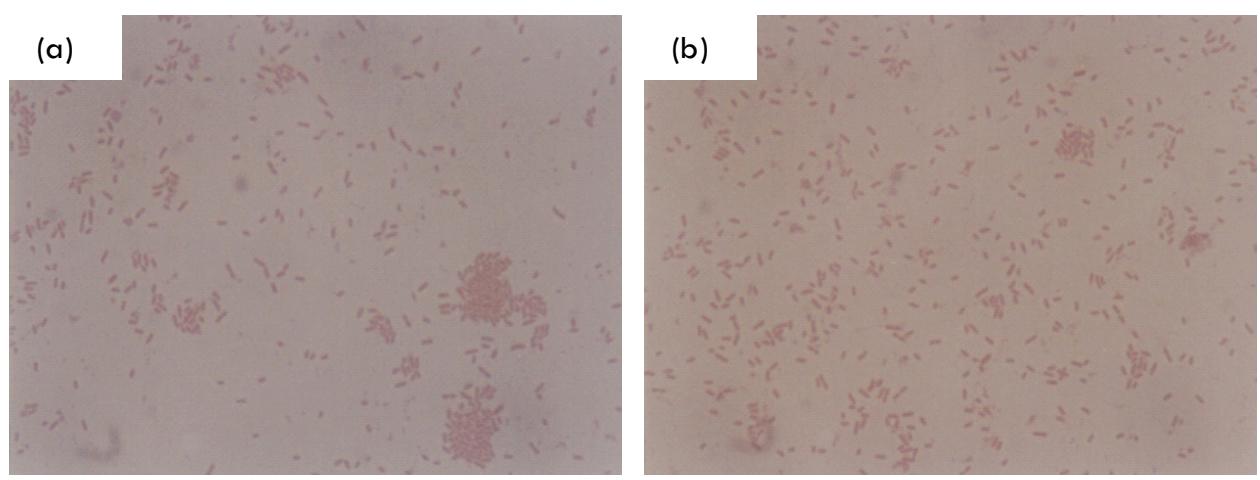

\section{(c)}

Figure 1. Micrographs of the selected bacterial strains (x 1,000). (a) KT22, Serratia sp., TNT removing strain; (b) KD4, Pseudomonas sp., 2,4-DNT removing strain; (c) KD6, Pseudomonas sp., 2,6-DNT removing strain. 


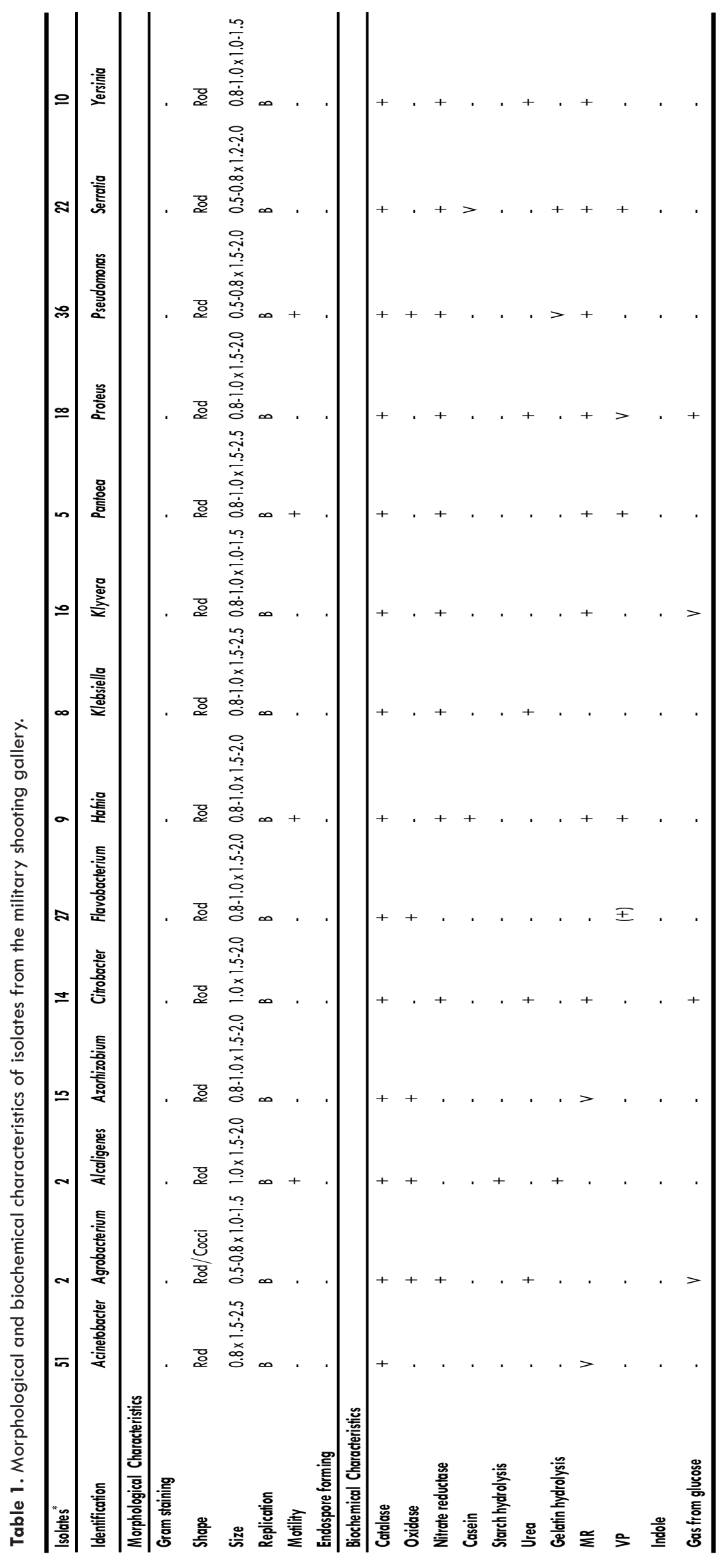


Table 2. Results of screening tests for selected isolates.

\begin{tabular}{lcccccccc}
\hline Explosive & Strain No. & $\begin{array}{c}\text { Initial Conc. } \\
(\mathbf{m g} / \mathbf{L})\end{array}$ & $\begin{array}{c}\text { Final Conc. } \\
(\mathbf{m g} / \mathbf{L})\end{array}$ & R.E. $(\%)$ & Strain No. & $\begin{array}{c}\text { Initial Conc. } \\
(\mathbf{m g} / \mathbf{L})\end{array}$ & $\begin{array}{c}\text { Final Conc. } \\
(\mathbf{m g} / \mathbf{L})\end{array}$ & R.E. (\%) \\
\hline \multirow{4}{*}{ TNT } & KT22 & 107.7 & 0.0 & 100.0 & KT60 & 107.7 & 41.7 & 61.3 \\
& KT23 & 107.7 & 4.2 & 96.1 & KT88 & 144.5 & 71.5 & 50.5 \\
& KT92 & 107.7 & 11.2 & 89.6 & KT147 & 107.7 & 59.8 & 44.5 \\
& KT76 & 107.7 & 19.7 & 81.7 & KT43 & 107.7 & 72.4 & 32.8 \\
& KT104 & 107.7 & 32.0 & 70.3 & KT110 & 107.7 & 95.2 & 11.6 \\
\hline \multirow{4}{*}{ 2,4-DNT } & KD4 & 68.1 & 0.0 & 100.0 & KD27 & 125.0 & 46.0 & 63.0 \\
& KD9 & 125.0 & 0.5 & 99.6 & KD14 & 125.0 & 84.5 & 32.4 \\
& KD28 & 125.0 & 0.6 & 99.5 & KD3 & 68.1 & 49.1 & 27.9 \\
& KD23 & 125.0 & 17.7 & 85.8 & KD13 & 125.0 & 104.2 & 16.6 \\
\hline \multirow{5}{*}{ 2,6-DNT } & KD6 & 103.9 & 2.4 & 97.7 & KD53 & 71.4 & 30.9 & 56.7 \\
& KD59 & 103.9 & 4.3 & 95.9 & KD55 & 103.9 & 64.0 & 38.4 \\
& KD64 & 103.9 & 12.7 & 87.8 & KD62 & 103.9 & 79.8 & 23.2 \\
& KD58 & 103.9 & 30.0 & 71.1 & KD63 & 103.9 & 97.3 & 6.4 \\
\hline
\end{tabular}

R.E.: removal efficiency.

Table 3. Morphological and biochemical characteristics of the selected isolates (KT22, KD4, and KD6) with the highest explosives removal efficiencies.

\begin{tabular}{|c|c|c|c|}
\hline Strain & КT22 & KD4 & KD6 \\
\hline Shape & Rod & Rod & Rod \\
\hline Size $(\mu \mathrm{m})$ & $0.8 \times 2.0$ & $0.8 \times 2.0-2.5$ & $0.8 \times 1.5$ \\
\hline Gram & - & - & - \\
\hline Reproduction & B & B & B \\
\hline Motility & + & + & + \\
\hline \multicolumn{4}{|l|}{ Endospore } \\
\hline \multicolumn{4}{|l|}{ forming } \\
\hline Catalase & + & + & + \\
\hline Oxidase & - & + & + \\
\hline Nitrate reductase & + & + & + \\
\hline Casein & - & - & - \\
\hline Starch & - & - & + \\
\hline Urea & - & + & - \\
\hline Gelatin & - & - & \\
\hline MR & $(+)$ & - & \\
\hline VP & + & - & - \\
\hline Indole & - & - & \\
\hline Gas from glucose & & & \\
\hline
\end{tabular}

B: binary replication, $\mathrm{V}$ : various results, +: positive reaction, -: negative reaction, and weak reaction is given in the parentheses.

\section{Batch Culture}

Three bacterial strains (KT22, KD4, and KD6) which showed the highest explosives removal efficiencies were selected for the batch experiments in order to determine optimal culture conditions. Effects of various factors, including cell concentrations, explosives concentrations, medium composition, temperature, $\mathrm{pH}$, and pure vs. mixed cultures, on explosives removal efficiencies were evaluated.

\section{Determination of Optimal Cell Concentration}

In order to determine the optimum cell concentration for the removal of TNT, different cell concentrations $(0.5,1.0,1.5$, and
$2.0 \mathrm{~g} \mathrm{WCW} / \mathrm{L})$ of KT22 strain and the Stanier's basal mineral medium were used. As shown in Table 4, the removal efficiency for TNT used as sole carbon source was $38.8,51.2,49.5$, and $52.5 \%$ at the cell concentration of $0.5,1.0,1.5$, and 2.0 $\mathrm{g} \mathrm{WCW} / \mathrm{L}$, respectively, after $6 \mathrm{~h}$ of incubation. Therefore, the optimum cell concentration was determined as $1 \mathrm{~g} / \mathrm{L}$ because the higher amount of biomass at $2.0 \mathrm{~g} / \mathrm{L}$ did not show significantly higher TNT removal efficiency.

\section{Effects of Explosives Concentrations on Bacterial Growth Rates}

Using the cell concentration of $1 \mathrm{~g} \mathrm{WCW} / \mathrm{L}$, effects of explosives concentrations on bacterial growth rates were evaluated. Three different concentrations $(10,100,200 \mathrm{mg} / \mathrm{L})$ of TNT and 
2,4/2,6-DNT in the basal mineral medium were used. Results showed the higher bacterial growth rate and TNT removal efficiency at the lower TNT concentration (Figure $2 a$ and Table 5). Likewise, 2,4-DNT showed similar effects for KD4 strain (Figure 2b). However, in case of 2,6-DNT, KD6 strain showed similar growth rates regardless of 2,6-DNT concentrations (Figure 2c).

\section{Effect of Medium Composition on Explosives Removal Efficiency}

To determine the effect of medium composition on the explosive removal efficiency, LB medium and Stanier's basal mineral medium were compared, using KT22, KD4, and KD6 strains. The TNT removal efficiency for KT22 was $99.7 \%$ in LB medium and $51.2 \%$ in Stanier's basal medium, and the 2,4/2,6-DNT removal efficiency for KD4 and KD6 was $99.1 \%$ and $92.7 \%$ in LB medium and $63.0 \%$ and $34.5 \%$ in Stanier's basal medium, respectively. Therefore, each selected strain showed higher removal efficiency for the corresponding explosive in LB medium which is a rich medium containing additional carbon and nitrogen sources such as peptone and yeast extract, compared to Stanier's basal mineral medium which contained explosives as sole carbon sources.

These results are also in good agreements with previously published studies on the effects of supplemental nitrogen sources and carbon sources on the biodegradation of TNT (Won et al., 1974; Boopathy et al., 1997; Park et al., 2003). These studies showed that in the presence of other carbon sources except aspirate, Pseudomonas putida U-T202 could degrade TNT over $92 \%$ and showed a good biomass growth after $30 \mathrm{~h}$ of incubation (Park et al., 2003; Won et al., 1974) also reported that the TNT oxidation required the addition of glucose or nitrogenous substances to achieve accelerated transformation and in a medium supplemented with $0.5 \%$ yeast extract, $100 \mathrm{mg} / \mathrm{L}$ of TNT was completely transformed to intermediates such as monoamino- dinitrotolvene (MADNT), diaminomononitrotolvene, or azoxy compound.

Table 4. Effect of cell concentrations of KT22 strain on TNT removal efficiency.

\begin{tabular}{cccc}
\hline Cell Conc. $(\mathbf{g}(\mathbf{W C W}) / \mathbf{L})$ & Oh $(\mathbf{m g} / \mathbf{L})$ & $\mathbf{6 h}(\mathbf{m g} / \mathbf{L})$ & R.E. $(\%)$ \\
\hline 0.5 & 84.7 & 51.9 & 38.8 \\
1.0 & 84.7 & 41.5 & 51.2 \\
1.5 & 84.7 & 42.8 & 49.5 \\
2.0 & 84.7 & 40.2 & 52.5 \\
\hline
\end{tabular}

WCW: Wet Cell Weight, R.E.: removal efficiency.

Table 5. Effects of explosives concentrations on removal efficiencies.

\begin{tabular}{|c|c|c|c|c|c|c|c|c|c|}
\hline \multirow{2}{*}{$\begin{array}{l}\text { Explosive Conc. } \\
\text { (mg/L) }\end{array}$} & \multicolumn{3}{|c|}{ TNT } & \multicolumn{3}{|c|}{ 2,4-DNT } & \multicolumn{3}{|c|}{ 2,6-DNT } \\
\hline & $\mathrm{Oh}(\mathrm{mg} / \mathrm{l})$ & $6 \mathrm{~h}(\mathrm{mg} / \mathrm{l})$ & R.E. (\%) & $\mathrm{Oh}(\mathrm{mg} / \mathrm{l})$ & $12 \mathrm{~h}(\mathrm{mg} / \mathrm{l})$ & R.E.(\%) & $\mathrm{Oh}(\mathrm{mg} / \mathrm{l})$ & $18 \mathrm{~h}(\mathrm{mg} / \mathrm{l})$ & R.E. (\%) \\
\hline 10 & 9.6 & 5.1 & 46.9 & 9.1 & 0.0 & 100.0 & 12.5 & 8.1 & 35.5 \\
\hline 100 & 76.5 & 37.9 & 50.3 & 89.4 & 33.1 & 63.0 & 103.9 & 68.0 & 34.5 \\
\hline 200 & 149.4 & 121.2 & 18.9 & 166.7 & 74.7 & 55.2 & 192.0 & 172.7 & 10.1 \\
\hline
\end{tabular}

R.E.: removal efficiency.

\section{Determination of Optimum Temperature and $\mathrm{pH}$}

For the ranges of temperature $\left(15-30^{\circ} \mathrm{C}\right)$ and $\mathrm{pH}(5-8)$ tested in this study, the explosive removal efficiencies for those three selected strains were the highest at around $25^{\circ} \mathrm{C}$ and at $\mathrm{pH} 7$, as shown in Figures 3 and 4.

\section{Explosive Removal Efficiency for Mixed Culture}

To further investigate the effect of the presence of pure culture (containing one type of explosive-removing strain) vs. mixed culture (containing more than one type of explosive-removing strains) on the explosive removal efficiency, KT22 strain which showed a high TNT removal efficiency was used as a representative TNT-removing strain. For the mixed culture, KT22 strain was mixed with Bacillus or Pseudomonas strain, both commonly occurring soil bacteria, or with purple non-sulfur bacterial strain capable of degrading some recalcitrant organic compounds. As shown in Figure 5, TNT removal was the highest for the mixed culture consisting of KT22 and Bacillus sp., with the removal efficiency of $76.6 \%$ after $6 \mathrm{~h}$, compared to $51.2 \%$ when KT22 strain used alone.

This study carries several significant scientific and industrial application merits. Firstly, Serratia sp. has been rarely reported for its efficiency in TNT biodegradation. Moreover, three bacterial strains (Serratia sp. KT22, Klebsiella sp. KD4, and Klebsiella sp. KD6) showed higher removal efficiencies on the explosives than the efficiencies reported in other previous studies. Finally, Serratia sp. KT 22 showed synergistic removal efficiency in a mixed culture with Bacillus sp. 

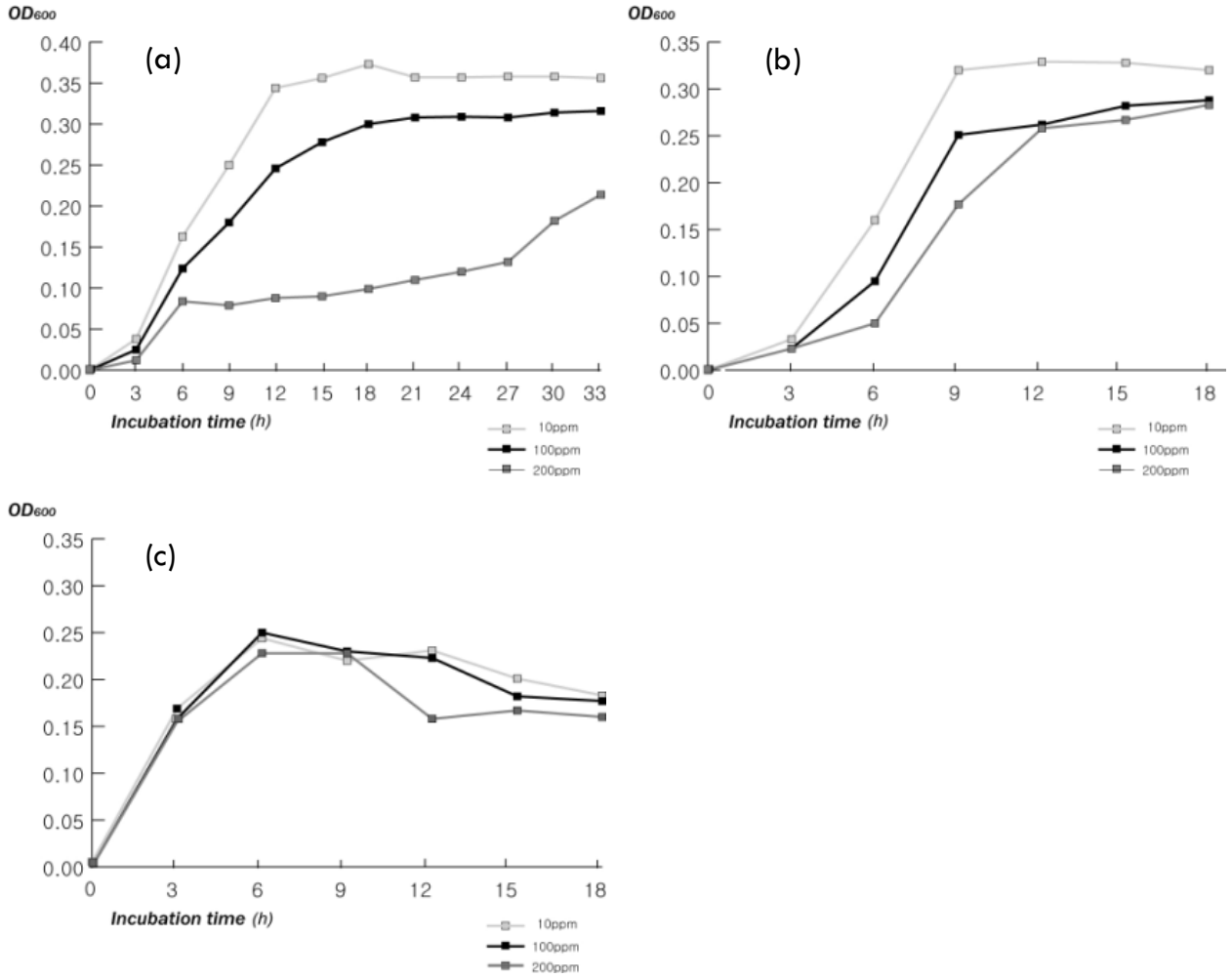

Figure 2. Effects of explosives concentrations on bacterial growth rates. (a) Effect of TNT concentrations on growth of KT22; (b) Effect of 2,4-DNT concentrations on growth of KD4; (c) Effect of 2,6-DNT concentrations on growth of KD6.
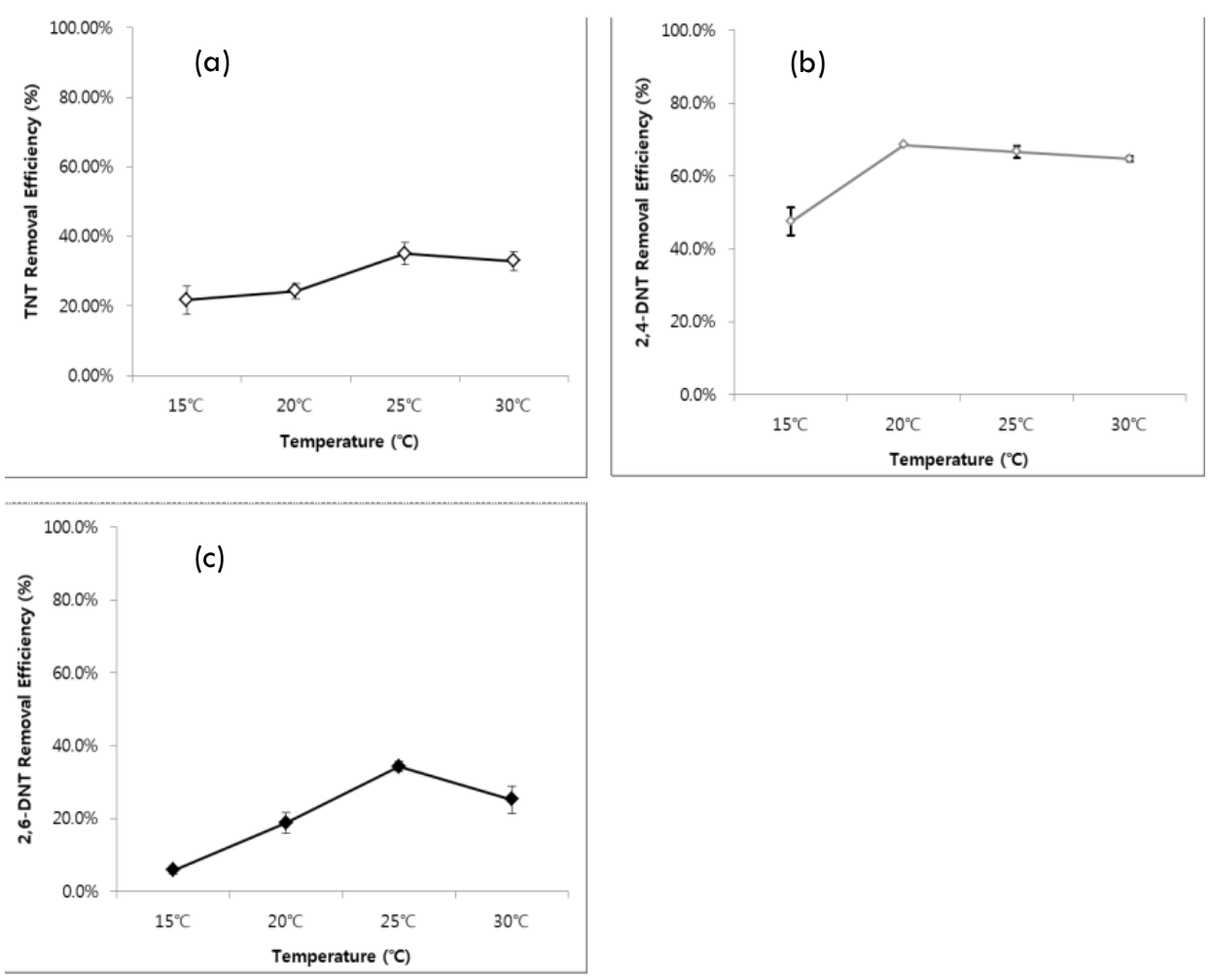

Figure 3. Effect of temperature on explosive removal efficiency. 


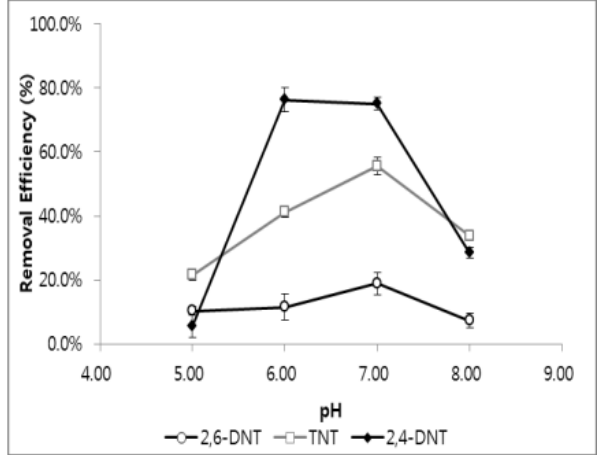

Figure 4. Effect of pH on explosive removal efficiency.

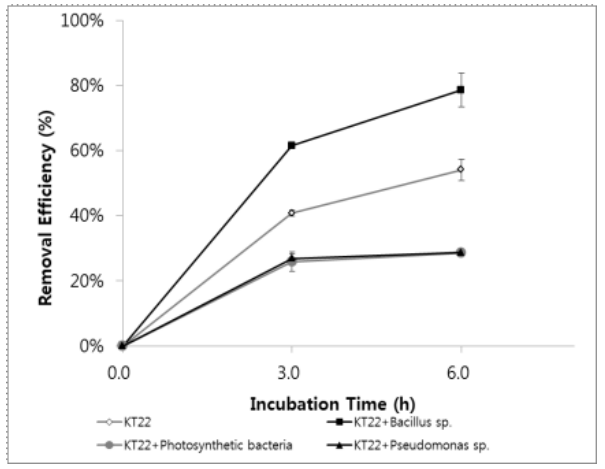

Figure 5. Effect of mixed culture on TNT removal efficiency.

Despite the significant level of advancement made in the environmental remediation techniques by using chemical, physical and biological media, numerous side effects induced by chemicals used or the underlying challenges in identifying the bacteria with high removal efficiency always have been limiting factors. The new strategic approaches preferred by may municipal and governmental agencies around the world, however, are dominantly bacteria-using bioremediation techniques. Therefore, the bacterial strains with higher bioremediation potency shown here could further facilitate explosive cleaning up processes in real life applications in addition to the scientific values mentioned somewhere else in this report.

\section{Acknowledgments}

This study was supported by a grant from the Korean Ministry of Environment. Donggiun Kim was supported by the Environmental Biotechnology National Core Research Center (R15-2003-012$010021)$ and post - BK21 Program.

\section{References}

Alef K and P Nannipieri (1995) Methods in Applied Soil Microbiology and Biochemistry. Academic Press. London, UK.

Alexander M (1967) The breakdown of pesticides in soils. American Association for the Advancement of Science. Washington, DC, USA. Arp DJ, CM Yeager, and MR Hyman (2001) Molecular and cellular fundamentals of aerobic cometabolism of trichloroethylene. Biodegradation. 12: 81-103.

Atlas RM (1993) Handbook of Microbiological Media, CRC Press. Florida, USA.

Boopathy R, DL Widrig, and JF Manning (1997) In situ bioremediation of explosives contaminated soil: a soil column study. Bioresource Technol. 59: 169-176.

Bridge JE, C Swanston, RE Lane, and TP Davis (1942) Trinitrotoluene poisoning. Proc R Soc Lond[Biol]. 35: 553-590.

Cappuccino JG and N Sherman (2001) Microbiology -A Laboratory Manual. 6th ed. Benjamin Cummings.

Channon HJ, GT Mills, and RT Williams (1994) The metabolism of 2,4,6-trinitrotoluene (TNT). Biochem. J. 38: 70-85.

Dagley $S$ and MD Patel (1957) Oxidation of p-cresol and related compounds by a Pseudomonas. Biochem. J. 165: 395-402.

Dale HH (1921) The fate of TNT in the animal body. Med Res Counc(GB) Spec Rep Ser 58: 53-61.

Demain AL, JE Davies, RM Atlas, G Cohen (1999) Manual of Industrial Microbiology and Biotechnology. 2nd ed. ASM Press. USA.

Foster JW (1962) Bacterial oxidation of hydrocarbons. Academic Press, Inc. New York, NY, USA.

French CE, S Nicklin, and NC Bruce (1998) Aerobic Degradation of 2,4,6-Trinitrotoluene by Enterobacter cloacae PB2 and by Pentaerythritol Tetranitrate Reductase. Appl. Environ. Microbiol. 64: 28642868.

Funk SB, DJ Roberts, DL Crawford, and RL Crawford (1993) InitialPhase Optimization for Bioremediation of Munition Compound-Contaminated Soils. Appl. Envrion. Microbiol. 59: 2171-2177.

Hamilton A (1921) Trinitrotolvene as an industrial poison. J. Ind. Hyg. 3:102-116.

Jessen HL (1957) Decomposition of chloro-substituted aliphatic acids by soil bacteria. Can. J. Microbiol. 3: 151-164.

Kalafut T, ME Wales, VK Rastogi, RP Naumova, SK Zaripova, and JR Wild (1998) Biotransformation Patterns of 2,4,6-Trinitrotolvene by Aerobic Bacteria. Current Microbiol. 36: 45-54.

Kim HY and HG Song (2000) Comparison of 2,4,6-Trinitrotoluene Degradation by Seven Strains of White Rot Fungi. Current Microbiol. 41: 317-320.

Klausmeier RE, JL Osmon, and DR Walls (1973) The Effect of Trinitrotolvene on Microorganisms. Dev. Ind. Microbiol. 15: 309-317.

Krieg NR, JG Holt, and RGE Murray (1994) Bergey's Manual of Systematic Bacteriology. Williams \& Wilkins.

Lee T (1996) Trinitrotolvene (TNT) Biotransformation Pathways Under Aerobic and Anaerobic Condition. Environ. Eng. Res. 1: 81-87.

Montemagno CD and RL Irvine (1990) Feasibility of Biodegrading TNTContaminated Soils in a Slurry Reactor. Environ. Assess. and Info. Science Division, CETHA-TE-CR-90062. Argonne National Laboratory, Argonne, IL 60439-4801, USA.

Park C, TH Kim, S Kim, SW Kim, J Lee, and SH Kim (2003) Optimization for biodegradation of 2,4,6-trinitrotolvene (TNT) by Pseudomonas putida. J. Biosci. Bioeng. 95: 567-571.

Park C, TH Kim, S Kim, J Lee, and SW Kim (2002) Biokinetic Parameter Estimation for Degradation of 2,4,6-Trinitrotoluene (TNT) with Pseudomonas putida KP-T201. J. Biosci. Bioeng. 94: 57-61.

Preslan JE, BB Hartel, M Emerson, L White, and WJ George (1993) An Improved Method for Analysis of 2,4,6-Trinitrotoluene and Its Metabolites from Compost and Contaminated Soils. J. Hazard. Mater. 33: 329-337.

Sax NI (1963) Dangerous properties of industrial materials. 2nd ed. Reinhold Publishing Corp. New York, USA.

Scheibner K, M Hofrichter, A Herre, and J Michels (1997) Screening for fungi intensively mineralizing 2,4,6-trinitrotolvene. Appl. Microbiol. Biotechnol. 47: 452-457. 
Smock LA and KL Stoneburner, JR Clark (1976) The toxic effects of trinitrotolvene (TNT) and its primary degradation products on two species of algae and the fathead minnow [Selenastrum capricoenutum, Microcystis aeruginosa]. Wat. Res. 10: 537-543.

Voegtlin C, CW Hooper, and JM Johnson (1919) Trinitrotolvene poisoning. US Public Health Rep 34:1307-1313.

Walsh ME (2001) Determination of nitroaromatic, nitramine, and nitrate ester explosives in soil by gas chromatography and an electron capture detector. Ealanta 54: 427-438.

Weaver RW, S Angle, P Bottomley, D Bezdic, S Smith, A Tabatabai, and A Wollum (1944) Methods of Soil Analysis -Part 2 Microbiological and Biochemical Preperties. Soil Science Society of America. Madison, Wis., USA.

Williams RT, PS Ziegenfuss, and WE Sisk (1992) Composting of Explosives and Propellant Contaminated Soils under Themophilic and Mesophilic Conditions. J. Ind. Microbiol. 9: 137-144.

Won WD, LH Disalvo, and J Ng (1976) Toxicity and mutagenicity of 2,4,6-trinitrotoluene and its microbial metabolites. Appl. Environ. Microbiol. 31: 576-580.

Won WK, RJ Heckly, DJ Glocer, and JC Hoffsommer (1974) Metabolic Dispositions of 2,4,6-Trinitrotolvene. Appl. Environ. Microbiol. 27: 513-516. 